\title{
CHILDLESSNESS PREDICTS HELPING OF NIECES AND NEPHEWS IN UNITED STATES, 1910
}

\author{
THOMAS V. POLLET* AND ROBIN I. M. DUNBAR $\uparrow$ \\ * Centre for Behaviour and Evolution, Newcastle University, UK and $\dagger$ Institute of \\ Cognitive \& Evolutionary Anthropology, University of Oxford, UK
}

\begin{abstract}
Summary. The 'helpers at the nest' hypothesis suggests that individuals who are not currently reproducing often help kin by caretaking and thereby increase their inclusive fitness. Using a large scale historical dataset (Integrated Public Use Microdata Series sample of $1910 ; n=13,935)$, the hypothesis is tested that childless couples are more likely to fulfil such a role by taking care of a niece or nephew, but not a parent, than couples with children. Childless couples were significantly more likely to take care of a niece or nephew than couples with children. In contrast, couples with children and childless couples did not differ in caretaking of parents. Childless couples were also more likely to have more and younger nieces/nephews in their home than couples with children.
\end{abstract}

\section{Introduction}

Studies from behavioural ecology have shown that, in a wide variety of species, individuals of low current reproductive value often help a (related) breeding pair (for example: scrub jays: Woolfenden, 1975; striped mouse (Rhabdomys pumilio): Schradin \& Pillay, 2004; for review: Emlen, 1984). In line with Hamilton's rule (1964), this helping behaviour is predicted to increase their inclusive fitness. In humans, similar effects appear to exist: kin often help by providing childcare (for example Turke, 1988, 1989; Sear \& Mace, in press). For instance, maternal grandmothers, in traditional societies as well as in historical populations, provide help which has beneficial effects on their inclusive fitness (Hawkes et al., 1997; Sear et al., 2000, 2002, 2003; Voland \& Beise, 2002; Beise, 2004; Lahdenperä et al., 2004). Older siblings have also been thought to fulfil similar helper roles (Weisner \& Gallimore, 1977; but see Crognier et al., 2001; Bereczkei \& Dunbar, 2002). Among the Toba of Argentina for instance, girl helpers were shown to significantly reduce the workload of the mother by helping and caretaking (Bove et al., 2002; but see Hames \& Draper, 2004). However, surprisingly little research has examined similar helping behaviour by childless individuals. 
For modern societies, Essock-Vitale and McGuire (1985) have shown that childless women are more likely to give and receive help from kin. Childless women are also more likely to have had recent contact with their siblings and nieces/nephews than mothers (Pollet, 2005; Pollet et al., 2006). Yet, no such difference between childless women and mothers was found in their relationships with uncles and aunts. This suggests that childless women might be taking reproductive value (i.e. the beneficiary's capacity to reproduce in the future, and thus contribute to the carer's fitness: Hughes, 1988) into account. Here, helping behaviour by childless couples in a historical population sample - American households from 1910 - is examined. Early in the twentieth century, the American population was declining and there was further migration towards the West of the United States (Hobbs \& Stoops, 2002). Households were also becoming progressively smaller (Kobrin, 1976). Childlessness was rising, although there were considerable differences between regions (Morgan, 1991). Therefore, the American population in the early twentieth century is an interesting study population to test the consequences of childlessness on caretaking behaviour. No other studies have thoroughly investigated the possible effect of childlessness on caretaking decisions using a large demographic sample. The hypothesis tested here is that childless couples will be more likely to take care of nieces and nephews than couples with children. A possible alternative hypothesis is that childless couples would help any genetic relative, regardless of that relative's reproductive value, as they have more resources. In order to rule out this alternative, the role of childlessness for the frequency of caretaking of nieces and nephews will be compared with frequency of caretaking of parents (who, being older, will typically have lower reproductive value). In addition, resource availability is controlled for by coding the occupational prestige of the male household head and ownership of the dwelling. In addition, possible interaction effects on caretaking of nieces and nephews will be tested for: for example, couples should be more inclined to take care of a niece or nephew, if the spouse's age is high and the couple is childless.

\section{Methods}

The Integrated Public Use Microdata Series (IPUMS) sample of 1910 contains data on demographics and household composition (Ruggles et al., 1997). It was a 1 in 250 random sample of the total population of the USA.

The presence of nieces/nephews or parents for two-headed households was analysed. Two-headed households form the large majority of the sample $(>80 \%)$. In the sample, parents and nieces/nephews are defined as being related only to the male household head for two-headed households $(n=14,037)$. For this sample, the presence of nieces and nephews related to the woman in a two-headed household is far less common (niece or nephew of spouse present $<0.05 \%(n=5)$ vs niece or nephew from husband present $2 \cdot 2 \%(n=313)$; Fisher's Exact test: $p=0 \cdot 005)$. Women who did not have any surviving (biological) children at the time of the survey were coded as 'childless'. Cases where the wife was coded as childless but the husband still had genetic children living with them were excluded ( $0 \cdot 7 \%$; final sample: 13,935$)$.

Caretaking is measured as being part of the household at the time of the survey. Co-residence can be seen as a cost. Having a parent or a niece/nephew in one's 
Table 1. Descriptive statistics of the variables ( $n=13,935$, unless stated otherwise)

\begin{tabular}{|c|c|c|}
\hline Variables & Categories & Frequencies/means \\
\hline \multirow[t]{2}{*}{ Childlessness } & Has children & $n=11,603$ \\
\hline & Childless (no surviving children) & $n=2332$ \\
\hline $\begin{array}{l}\text { Occupational status of male } \\
\text { household head }\end{array}$ & (interval; ranges from 0 to 100 ) & $25 \cdot 82(\mathrm{SD}=22 \cdot 21)$ \\
\hline \multirow[t]{3}{*}{ House ownership } & Owns or being bought & $n=6252$ \\
\hline & Rents & $n=7418$ \\
\hline & Unknown & $n=265$ \\
\hline \multirow[t]{2}{*}{ Urbanization } & Urban & $n=6493$ \\
\hline & Rural & $n=7442$ \\
\hline Age of woman & (interval) & $38 \cdot 12$ years $(\mathrm{SD}=12 \cdot 71)$ \\
\hline \multirow[t]{4}{*}{ 'Caretaking' (dependent) } & $\begin{array}{l}\text { No niece/nephew or parent in } \\
\text { household }\end{array}$ & $n=13,274$ \\
\hline & Niece/nephew in household & $n=294$ \\
\hline & Parent in household & $n=348$ \\
\hline & $\begin{array}{l}\text { Niece/nephew and parent in } \\
\text { household }\end{array}$ & $n=19$ \\
\hline $\begin{array}{l}\text { Number of nieces/nephews } \\
\text { present }\end{array}$ & (interval; dependent; $n=13,935$ ) & $0 \cdot 03(\mathrm{SD}=0 \cdot 22)$ \\
\hline Mean age niece/nephew & (interval; dependent; $n=309$ ) & $14 \cdot 21$ years $(S D=8 \cdot 16)$ \\
\hline Mean age niece/nephew $(\leq 18)$ & (interval; dependent; $n=224$ ) & $10 \cdot 36$ years $(S D=5 \cdot 13)$ \\
\hline
\end{tabular}

household represents a (net) cost, not only in space but probably financially since this extra person has to eat. The IPUMS is a cross-sectional set on household composition, so no data are available on the length of stay with the family. All the parents staying with a couple were out of the labour force and thus did not provide a direct financial benefit. While the net cost of having a parent might differ from having a niece or nephew, in both cases having a relative in the household would produce a (net) cost. Therefore, in both cases temporarily having a relative in the household can be seen as 'helping'.

Besides ownership of the house, the occupational prestige of the male household head was scored in terms of the Duncan SEI score of 1950 (see Haug, 1977) to control for resource availability. In addition, the age of the woman and urbanization were controlled for (Table 1). Squared age of the woman was also tested. Additional information about the IPUMS set can be obtained from Ruggles et al. (1997).

As a first step, the role of childlessness for the presence of a niece or nephew or a parent was examined. Backward stepwise multinomial logistic regression (MLR) was used to obtain parameter estimates (Menard, 1995; Pampel, 2000), as this is a more cautious way of testing hypotheses than forward stepwise. For these logistic regression models, the likelihood ratio tests and Wald statistics for individual parameters are reported. Nineteen cases where both a parent and a niece/nephew were present were excluded from this analysis (fifteen couples with children and four without children) because this category is problematic for obtaining parameter 
Table 2. Parameter estimates for variables in logistic regression model with reference category 'no parent or niece or nephew present'

\begin{tabular}{|c|c|c|c|c|c|c|c|c|}
\hline & & $\lambda$ & SE & Wald & $\mathrm{df}$ & $p_{\text {Wald }}$ & $\operatorname{Exp}(\lambda)$ & $p_{\text {LLR }}$ \\
\hline \multicolumn{9}{|c|}{ Niece/nephew present } \\
\hline & Intercept & $-7 \cdot 88$ & $0 \cdot 7$ & $128 \cdot 58$ & 1 & $<0 \cdot 001$ & & \\
\hline Childlessness & Childless & $1 \cdot 3$ & $0 \cdot 13$ & $102 \cdot 5$ & 1 & $<0 \cdot 001$ & $3 \cdot 66$ & $<0 \cdot 001$ \\
\hline Age woman & (increase by one year) & $0 \cdot 198$ & 0.03 & $35 \cdot 5$ & 1 & $<0 \cdot 001$ & $1 \cdot 22$ & $<0 \cdot 001$ \\
\hline$(\text { Age woman })^{2}$ & & -0.002 & $0 \cdot 0003$ & $29 \cdot 65$ & 1 & $<0.001$ & 0.998 & $<0.001$ \\
\hline Urbanization & Urban & $-0 \cdot 341$ & $0 \cdot 124$ & $7 \cdot 59$ & 1 & $0 \cdot 006$ & $0 \cdot 7$ & $0 \cdot 006$ \\
\hline \multirow[t]{3}{*}{ House ownership } & Unknown & $-0 \cdot 01$ & $0 \cdot 47$ & $0 \cdot 001$ & 1 & $0 \cdot 98$ & 0.99 & $<0.001$ \\
\hline & Rents & $0 \cdot 16$ & $0 \cdot 13$ & $1 \cdot 48$ & 1 & $0 \cdot 24$ & $1 \cdot 12$ & \\
\hline & Owns or being bought & 0 & - & - & 0 & - & - & \\
\hline \multicolumn{9}{|l|}{ Parent present } \\
\hline & Intercept & $-4 \cdot 24$ & $0 \cdot 66$ & $41 \cdot 1$ & 1 & $<0 \cdot 001$ & & \\
\hline Childlessness & Childless & $0 \cdot 19$ & $0 \cdot 14$ & $0 \cdot 33$ & 1 & $0 \cdot 188$ & $1 \cdot 21$ & $<0 \cdot 001$ \\
\hline Age woman & (increase by one year) & $0 \cdot 11$ & $0 \cdot 04$ & $8 \cdot 8$ & 1 & 0.003 & $1 \cdot 11$ & $<0.001$ \\
\hline$(\text { Age woman })^{2}$ & & -0.002 & $0 \cdot 0005$ & $16 \cdot 37$ & 1 & $<0 \cdot 001$ & 0.998 & $<0.001$ \\
\hline Urbanization & Urban & $-0 \cdot 19$ & $0 \cdot 11$ & $2 \cdot 64$ & 1 & $0 \cdot 1$ & $0 \cdot 81$ & $0 \cdot 006$ \\
\hline \multirow[t]{3}{*}{ House ownership } & Unknown & -0.03 & $0 \cdot 34$ & $0 \cdot 01$ & 1 & $0 \cdot 936$ & $1 \cdot 02$ & $<0 \cdot 001$ \\
\hline & Rents & -0.58 & $0 \cdot 12$ & $32 \cdot 24$ & 1 & $<0.001$ & $0 \cdot 56$ & \\
\hline & Owns or being bought & 0 & - & - & 0 & - & - & \\
\hline
\end{tabular}

Note: parameter estimates are set to zero for reference category of ownership. This model contains the baseline effects only.

estimates in the MLR. In a second model, all possible interaction effects between independent variables were tested for.

Subsequently, backward stepwise linear regression models were constructed to determine whether childlessness independently affects both the number of nieces/ nephews in the household and the mean age of nieces/nephews in the household. As for the MLR analysis, linear regression models in which all possible interaction effects were tested were consequently also tested.

\section{Results}

The descriptive statistics of the variables are presented in Table 1. A simple $\chi^{2}$ test showed that childless couples are much more likely to have a niece or nephew present: 201 couples out of 11,603 couples with children had a niece/nephew versus 112 out of 2332 childless couples $(p=0 \cdot 0001)$. This remains the case if only the presence of nieces and nephews younger than 18 years is considered ( $\chi^{2}$ test; $\left.p<0.0001\right)$.

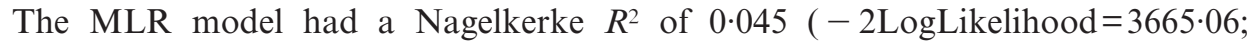
$\chi^{2}=222.53 ; p<0.0001 ;$ Table 2). All proposed variables (age, age ${ }^{2}$, childlessness, urbanization and house ownership), with the exception of occupational prestige of the male household, proved to be significant predictors (at $\alpha=0.05$ ) of caretaking patterns. 
Parameter estimates are best interpreted in terms of odds ratios $(\exp (\lambda))$. For couples with no surviving children the odds (niece/nephew in household versus no niece or nephew or parent in the household) were 3.66 times larger than for couples that did have children, even when controlling for other variables in the model (Table 2). However, childless couples were not significantly more likely than couples with children to have a parent in their household $\left(p_{\text {Wald }}=0 \cdot 18\right)$. By substituting the reference category of the dependent variable, whether childless couples are more likely to take care of a niece/nephew or of a parent can be examined. The odds for taking care of a niece/nephew versus a parent are 3.04 times larger for childless couples than for couples with children $\left(p_{\text {Wald }}<0 \cdot 0001\right.$; Table not shown).

The model with interaction effects showed an age $\times$ childlessness interaction effect and socioeconomic status $\times$ ownership on caretaking of a parent or a niece or nephew (Table 3). The model has a Nagelkerke $R^{2}$ of $0 \cdot 048(-2 \operatorname{LogLikelihood}=$ 3647.43; $\chi^{2}=240.61 ; p<0 \cdot 0001$; Table 3 ). This model shows that childless couples are more inclined to take care of a niece or nephew, instead of having neither a parent nor a niece or nephew in their household, if the spouse was older (odds ratio (childlessness $\times$ age of spouse): $1.03 ; p_{\text {Wald }}=0.006$ ). The model also shows an interaction effect between house ownership and household head socioeconomic status on caretaking of nieces and nephews. Couples where the husband has a high socioeconomic status but who rented their house were less likely to take care of a niece or nephew than couples where the husband has a high socioeconomic status and who owned (or were buying) their house (odds ratio (household head SEI $\times$ rents): $\left.0.989 ; p_{\text {Wald }}=0 \cdot 04\right)$.

If the analysis is limited to the presence of younger niece(s) or nephew(s), i.e. with a mean age of 18 years or younger, similar results are found. The odds for having a niece or nephew versus neither having neither a niece or nephew nor a parent in the household are 4.02 larger for childless couples than for couples with children ( $p_{\text {Wald }}<0 \cdot 0001$; model with baseline effects only; table not shown). The model with interaction effects, limited to the presence of younger niece(s) or nephew(s), shows similar effects as those described above (table not shown).

Childless couples also have significantly more nieces and nephews in their household than couples with children (final model $R^{2}$ : 0.009; Table 4). The model with interaction effects shows that childless couples where the spouse is older have more nieces and nephews in their household than childless couples where the spouse is younger (Table 5). Childless couples in rural areas were also more likely than childless couples in urban areas to have more nieces and nephews in their household.

Examining caretaking of nieces and nephews more closely, childless couples were found not to be significantly more likely to have younger nieces and nephews in their household than couples with children $(\beta=-0.08 ; t=-1.57 ; p=0.117$; table not shown). This conclusion was not altered for the model with interaction effects (Table not shown).

However, when examining caretaking of nieces/nephews with a mean age of 18 years or younger, childless couples are significantly more likely than parents to take care of younger nieces/nephews (final model $R^{2}=0 \cdot 14$; Table 4). The model with interaction effects showed that childless women who were older were more inclined to take care of older rather than younger nieces and nephews (Table 5). 
Table 3. Parameter estimates for variables in logistic regression model with reference category 'no parent or niece or nephew present'

\begin{tabular}{|c|c|c|c|c|c|c|c|c|}
\hline Variables & Categories & $\lambda$ & SE & Wald & df & $p_{\mathrm{Wald}}$ & $\operatorname{Exp}(\lambda)$ & $p_{\text {LLR }}$ \\
\hline \multicolumn{9}{|l|}{ Niece/nephew present } \\
\hline Childlessness & Childless & $0 \cdot 147$ & $0 \cdot 44$ & $0 \cdot 11$ & 1 & $0 \cdot 74$ & $1 \cdot 15$ & 0.94 \\
\hline Age of woman & (increase by one year) & $0 \cdot 178$ & $0 \cdot 03$ & $28 \cdot 4$ & 1 & $<0.001$ & $1 \cdot 2$ & $<0 \cdot 001$ \\
\hline$(\text { Age of woman })^{2}$ & & $-0 \cdot 002$ & $0 \cdot 0005$ & $27 \cdot 06$ & 1 & $<0.001$ & 0.998 & $<0 \cdot 001$ \\
\hline Urbanization & Urban & $-0 \cdot 34$ & $0 \cdot 13$ & $6 \cdot 73$ & 1 & $0 \cdot 01$ & $0 \cdot 72$ & $0 \cdot 006$ \\
\hline \multirow[t]{3}{*}{ Ownership } & Unknown & $-0 \cdot 13$ & $0 \cdot 75$ & $0 \cdot 03$ & 1 & $0 \cdot 86$ & $0 \cdot 8$ & $<0 \cdot 001$ \\
\hline & Rents & $0 \cdot 44$ & $0 \cdot 19$ & $5 \cdot 33$ & 1 & $0 \cdot 02$ & $1 \cdot 55$ & \\
\hline & Owns or being bought & 0 & - & - & 0 & - & - & \\
\hline Household head SEI & (increase by one unit) & $0 \cdot 006$ & $0 \cdot 004$ & $2 \cdot 26$ & 1 & $0 \cdot 13$ & $1 \cdot 006$ & na \\
\hline Age of woman $\times$ childless & (increase by one unit) & $0 \cdot 03$ & $0 \cdot 01$ & $7 \cdot 45$ & 1 & $0 \cdot 006$ & $1 \cdot 03$ & $0 \cdot 024$ \\
\hline \multirow[t]{3}{*}{ Ownership $\times$ household head SEI } & Unknown $\times$ SEI & $0 \cdot 003$ & $0 \cdot 017$ & 0.029 & 1 & $0 \cdot 87$ & $1 \cdot 003$ & $0 \cdot 047$ \\
\hline & Rents $\times$ SEI & $-0 \cdot 01$ & $0 \cdot 005$ & $4 \cdot 06$ & 1 & $0 \cdot 04$ & 0.989 & \\
\hline & Owns/being bought $\times$ SEI & 0 & - & - & 0 & - & - & \\
\hline \multicolumn{9}{|l|}{ Parent present } \\
\hline Childlessness & Childless & -0.04 & $0 \cdot 5$ & $0 \cdot 005$ & 1 & $0 \cdot 941$ & $0 \cdot 96$ & $<0 \cdot 001$ \\
\hline Age of woman & (increase by one year) & $0 \cdot 1$ & $0 \cdot 04$ & $7 \cdot 61$ & 1 & $<0.001$ & $1 \cdot 105$ & $<0 \cdot 001$ \\
\hline$(\text { Age of woman })^{2}$ & & $-0 \cdot 002$ & $0 \cdot 0005$ & $14 \cdot 36$ & 1 & $<0.001$ & 0.998 & $<0 \cdot 001$ \\
\hline Urbanization & Urban & $-0 \cdot 23$ & $0 \cdot 13$ & $3 \cdot 48$ & 1 & $0 \cdot 06$ & $0 \cdot 8$ & $0 \cdot 006$ \\
\hline \multirow[t]{3}{*}{ House ownership } & Unknown & 0.65 & $0 \cdot 46$ & $1 \cdot 91$ & 1 & $0 \cdot 16$ & $1 \cdot 92$ & $<0 \cdot 001$ \\
\hline & Rents & -0.73 & $0 \cdot 18$ & $16 \cdot 43$ & 1 & $<0.001$ & $0 \cdot 48$ & \\
\hline & Owns or being bought & 0 & - & - & 0 & - & - & \\
\hline Household head SEI & (increase by one unit) & $0 \cdot 001$ & $0 \cdot 003$ & $0 \cdot 04$ & 1 & $0 \cdot 85$ & $1 \cdot 001$ & na \\
\hline Age woman $\times$ childless & (increase by one unit) & $0 \cdot 007$ & $0 \cdot 015$ & $0 \cdot 202$ & 1 & $0 \cdot 65$ & $1 \cdot 007$ & $0 \cdot 024$ \\
\hline \multirow[t]{3}{*}{ Ownership $\times$ household head SEI } & Unknown $\times$ SEI & $-0 \cdot 03$ & $0 \cdot 02$ & $2 \cdot 23$ & 1 & $0 \cdot 14$ & 0.97 & $0 \cdot 047$ \\
\hline & Rents $\times$ SEI & $0 \cdot 006$ & $0 \cdot 005$ & $1 \cdot 32$ & 1 & $0 \cdot 25$ & $1 \cdot 006$ & \\
\hline & Owns/being bought $\times$ SEI & 0 & - & - & 0 & - & - & \\
\hline
\end{tabular}

Note: Parameter estimates are set to zero for reference category of ownership. This model includes interaction effects. The likelihood ratio test for household head SEI is not calculated as the degrees of freedom are set to 0 for this variable in this model. 
Table 4. Models and parameter estimates for stepwise ordinary least squares regression models (final models, baseline effects only)

\begin{tabular}{|c|c|c|c|c|c|}
\hline & & $R^{2}$ & $\beta$ & $t$ & $p$ \\
\hline \multicolumn{6}{|l|}{ Number of nieces/nephews } \\
\hline Intercept & & - & - & $2 \cdot 52$ & $0 \cdot 011$ \\
\hline Childlessness & Childless & $0 \cdot 006$ & $0 \cdot 09$ & $10 \cdot 47$ & $<0 \cdot 001$ \\
\hline Urbanization & Urban & $0 \cdot 001$ & -0.03 & $-4 \cdot 02$ & $<0 \cdot 001$ \\
\hline Age of woman & (increase by one SD) & $0 \cdot 0003$ & $0 \cdot 24$ & $4 \cdot 96$ & $<0 \cdot 001$ \\
\hline$(\text { Age of woman })^{2}$ & (increase by one SD) & $0 \cdot 001$ & $-0 \cdot 22$ & $-4 \cdot 6$ & $<0 \cdot 001$ \\
\hline \multicolumn{6}{|c|}{ Mean age of niece/nephew $(\leq 18)$} \\
\hline Intercept & & - & - & $0 \cdot 142$ & $0 \cdot 84$ \\
\hline Childlessness & Childless & $0 \cdot 021$ & $-0 \cdot 43$ & $-3 \cdot 51$ & $0 \cdot 001$ \\
\hline Household head SEI & (increase by one SD) & $0 \cdot 058$ & $0 \cdot 21$ & $3 \cdot 34$ & $0 \cdot 001$ \\
\hline Age of woman & (increase by one SD) & $0 \cdot 048$ & $0 \cdot 91$ & $2 \cdot 41$ & $0 \cdot 017$ \\
\hline$(\text { Age of woman })^{2}$ & (increase by one SD) & $0 \cdot 014$ & $0 \cdot 82$ & $-2 \cdot 18$ & $0 \cdot 031$ \\
\hline
\end{tabular}

Table 5. Models and parameter estimates for ordinary least squares regression models (final models, with interaction effects)

\begin{tabular}{|c|c|c|c|c|c|}
\hline & & $R^{2}$ & $\beta$ & $t$ & $p$ \\
\hline \multicolumn{6}{|l|}{ Number of nieces/nephews } \\
\hline Intercept & & - & - & $-3 \cdot 24$ & $0 \cdot 77$ \\
\hline Childlessness & Childless & $0 \cdot 006$ & $-0 \cdot 08$ & $-2 \cdot 14$ & $0 \cdot 032$ \\
\hline Urbanization & Urban & $0 \cdot 001$ & -0.02 & $-2 \cdot 14$ & $0 \cdot 032$ \\
\hline Age of woman & (increase by one SD) & $0 \cdot 001$ & $0 \cdot 11$ & $2 \cdot 1$ & 0.036 \\
\hline$(\text { Age of woman })^{2}$ & (increase by one SD) & $0 \cdot 001$ & $-0 \cdot 11$ & $2 \cdot 07$ & 0.039 \\
\hline Age $\times$ childless & & $0 \cdot 001$ & 0.62 & $4 \cdot 68$ & $<0 \cdot 001$ \\
\hline $\mathrm{Age}^{2} \times$ childless & & $0 \cdot 001$ & $-0 \cdot 3$ & $-4 \cdot 14$ & $<0 \cdot 001$ \\
\hline Urban $\times$ childless & & $0 \cdot 001$ & $-0 \cdot 12$ & $-4 \cdot 00$ & $<0.001$ \\
\hline \multicolumn{6}{|c|}{ Mean age of niece/nephew $(\leq 18)$} \\
\hline Intercept & & - & - & $0 \cdot 142$ & $0 \cdot 84$ \\
\hline Childlessness & Childless & $0 \cdot 021$ & $-0 \cdot 43$ & $-3 \cdot 51$ & 0.001 \\
\hline Household head SEI & (increase by one SD) & $0 \cdot 058$ & $0 \cdot 21$ & $3 \cdot 34$ & $0 \cdot 001$ \\
\hline Age of woman & (increase by one SD) & $0 \cdot 048$ & $0 \cdot 91$ & $2 \cdot 41$ & $0 \cdot 017$ \\
\hline$(\text { Age of woman })^{2}$ & (increase by one SD) & $0 \cdot 014$ & $0 \cdot 82$ & $-2 \cdot 18$ & $0 \cdot 031$ \\
\hline Age $^{2} \times$ childless & & $0 \cdot 021$ & $0 \cdot 34$ & $2 \cdot 62$ & 0.009 \\
\hline
\end{tabular}

\section{Discussion}

In line with the hypothesis that individuals of low current reproductive value should generally be more inclined to help kin with high reproductive value, childless couples are indeed found to be significantly more likely to take care of a niece/nephew than 
couples with children. It appears that these results cannot be explained by a simpler mechanism, namely helping any genetic relative. Additionally, it was found that if the couple was childless and the spouse was older, the couple was especially more likely to take care of a niece or nephew. The couple was also more likely to have more nieces and nephews present if they were childless and older. There was also an interaction effect between urbanization and childlessness on the number of nieces and nephews in the household. Childless couples in rural areas were more likely than childless couples from urban areas to have a niece or nephew in their household. This is in line with the idea that kinship obligations are typically stronger in rural areas than in urban areas (see Tönnies, 2002).

One of the limitations of the analyses is that there are no data available on the fitness consequences of household presence. Moreover, household composition is a rather crude measure of caretaking and no data are available on how long nieces/ nephews or parents remained in a given household. Yet, it is likely that in many cases nieces/nephews as well as parents were permanent members of the household who received help from the couple they were staying with. There are also no data available on whether nieces and nephews provide a benefit in terms of labour in the household. However, childless couples were significantly more likely than couples with children to have younger nieces and nephews in their household, and these are less likely to provide such a benefit. It was also not possible to determine whether childless couples were more likely than couples to take the parent of the niece or nephew - their sibling - in their household. Possibly further confounding variables, such as the overall number of siblings or birth order (for example: Pollet \& Nettle, 2007), might influence caretaking patterns of nieces and nephews. Unfortunately, these historical data on household composition do not allow these variables to be controlled for. Yet, it is unlikely that these variables would fully explain how childlessness influences (relative) caretaking patterns of individuals with high reproductive value.

The Nagelkerke $R^{2}$ of the model for presence of nieces/nephews or parents is low, indicating that a large amount of variance is unaccounted for. Nonetheless, there is a strong and significant difference between childless couples and couples with children in caretaking of nieces/nephews (odds ratio: $3 \cdot 6$ ), while controlling for other variables. Childless couples were also more likely to have both more and younger nieces/ nephews in their home than couples with children. These findings are consistent with kin selection theory, namely, individuals of low current reproductive value, such as childless individuals, should be more inclined to help related individuals with high reproductive value, all else being equal. In line with Essock-Vitale \& McGuire (1985) and Pollet et al. (2006), significant differences between childless individuals and individuals with children in patterns of caretaking of kin with high reproductive value were found. However, further research is necessary to investigate if these differentials in caretaking, between childless individuals and individuals with children, have measurable effects on an individual's inclusive fitness.

\section{Acknowledgments}

The authors are grateful to the IPUMS team (http://www.ipums.org) and the University of Minnesota for making the data presented here publicly available. Robin 
Dunbar's research is supported by the British Academy Centenary Project. The authors would like to thank Jenni Pettay, Mirkka Lahdenperä, Daniel Nettle, the editor and the anonymous reviewers for their very valuable feedback.

\section{References}

Beise, J. (2004) The Helping and the Helpful Grandmother - The Role of Maternal and Paternal Grandmothers in Child Mortality in the 17th and 18th Century Population of French Settlers in Quebec, Canada. MPIPDR Working Paper 2004-004. http://www.demogr.mpg.de/papers/ working/wp-2004-004.pdf (accessed 5th January 2007).

Bereczkei, T. \& Dunbar, R. I. M. (2002) Helpers-at-the-nest among Hungarian Gypsies. Current Anthropology 43, 804-809.

Bove, R. B., Vallegia, C. R. \& Ellison, P. T. (2002) Girl helpers and time allocation of nursing women among the Toba of Argentina. Human Nature 13, 457-472.

Crognier, E., Baali, A. \& Hilali, H. K. (2001) Do "helpers at the nest" increase their parents' reproductive success? American Journal of Human Biology 13, 365-373.

Emlen, S. T. (1984) Cooperative breeding in birds and mammals. In Krebs, J. B. \& Davies, N. B. (eds) Behavioral Ecology: An Evolutionary Approach. Sinauer Associates, Sunderland, MA, pp. 245-281.

Essock-Vitale, S. M. \& McGuire, M. T. (1985) Women's lives viewed from an evolutionary perspective. II. Patterns of helping. Ethology and Sociobiology 6, 155-173.

Hames, R. D. \& Draper, P. (2004) Women's work, childcare and helpers at the nest in a traditional hunter-gatherer society. Human Nature 15, 319-341.

Haug, M. R. (1977) Measurement of social stratification. Annual Review of Sociology 3, 51-77.

Hawkes, K., O'Connell, J. F. \& Blurton Jones, N. G. (1997) Hadza women's time allocation, offspring provisioning and the evolution of long postmenopausal life spans. Current Anthropology 38, 551-578.

Hobbs, F. \& Stoops, N. (2002) Demographic Trends in the 20th Century: Census 2000 Special Reports. US Census Bureau, Washington.

Hughes, A. (1988) Evolution and Human Kinship. Oxford University Press, Oxford.

Kobrin, F. E. (1976) The fall in household size and the rise of the primary individual in the United States. Demography 13, 127-138.

Lahdenperä, M., Lummaa, V., Helle, S., Tremblay, M. \& Russell, A. F. (2004) Fitness benefits of prolonged post-reproductive lifespan in women. Nature 428, 178-181.

Menard, S. (1995) Applied Logistic Analysis. Quantitative Applications in the Social Sciences Series \#106. Sage Publications, Thousand Oaks.

Morgan, S. P. (1991) Late nineteenth-and early twentieth-century childlessness. American Journal of Sociology 97, 779-807.

Pampel, F. C. (2000) Logistic Regression: A Primer. Quantitative Applications in the Social Sciences Series \#132. Sage Publications, Thousand Oaks.

Pollet, T. V. (2005) Childlessness and genetic relatedness: their influence on sibling ties in a Post-Industrial society. MSc Thesis, University of Liverpool, Liverpool.

Pollet, T. V., Kuppens, T. \& Dunbar, R. I. M. (2006) When nieces and nephews become important: Differences between childless women and mothers in relationships with nieces and nephews. Journal of Cultural and Evolutionary Psychology 4, 83-93.

Pollet, T. V. \& Nettle, D. (2007) Birth order and face-to-face contact with a sibling: Firstborns have more contact than laterborns. Personality and Individual Differences 43, 1796-1806. 
Ruggles, S., Sobek, M., Fitch, C. A., Hall, P. K. \& Ronnander, C. (1997) Integrated Public Use Microdata Series: Version 2.0. Historical Census Projects, University of Minnesota, Minneapolis.

Schradin, C. \& Pillay, N. (2004) The striped mouse (Rhabdomys pumilio) from the succulent karoo, South Africa: a territorial group-living solitary forager with communal breeding and helpers at the nest. Journal of Comparative Psychology 118, 37-47.

Sear, R. \& Mace, R. Who keeps children alive? A review of the effects of kin on child survival. Evolution and Human Behavior (in press).

Sear, R., Mace, R. \& McGregor, I. A. (2000) Maternal grandmothers improve nutritional status and survival of children in rural Gambia. Proceedings of the Royal Society of London Series $B$ 267, 1641-1647.

Sear, R., Mace, R. \& McGregor, I. A. (2003) The effects of kin on female fertility in rural Gambia. Evolution and Human Behavior 24, 99-112.

Sear, R., Steele, F., McGregor, I. A. \& Mace R. (2002) The effects of kin on child mortality in rural Gambia. Demography 39, 43-63.

Tönnies, F. (2002 [1887]) Community and Society. Dover, New York.

Turke, P. W. (1988) Helpers at the nest: childcare networks on Ifaluk. In Betzig, L. L., Borgerhoff-Mulder, M. \& Turke, P. W. (eds) Human Reproductive Behaviour. Cambridge University Press, Cambridge, pp. 178-188.

Turke, P. W. (1989) Evolution and the demand for children. Population and Development Review 15, 61-90.

Voland, E. \& Beise, J. (2002) Opposite effects of maternal and paternal grandmothers on infant survival in historical Krummhörn. Behavioral Ecology and Sociobiology 52, 435-443.

Weisner, T. S. \& Gallimore, R. (1977) My brother's keeper: child and sibling caretaking. Current Anthropology 18, 169-190.

Woolfenden, G. E. (1975) Florida Scrub Jay helpers at the nest. Auk 92, 1-15. 